Article

\title{
Intimate Partner Violence: The Predictive Power of Experiences in the Family of Origin and of Personality Disorder Traits
}

\author{
Marcela Madalena ${ }^{1, *}$ \\ Orcid.org/0000-0001-9397-3116 \\ Lucas de Francisco Carvalho ${ }^{2}$ \\ Orcid.org/0000-0002-3274-9724 \\ Denise Falcke ${ }^{1}$ \\ Orcid.org/0000-0002-4653-1216
}

${ }^{1}$ Universidade do Vale do Rio dos Sinos, São Leopoldo, RS, Brasil

${ }^{2}$ Universidade São Francisco, Itatiba, SP, Brasil

\begin{abstract}
Family-of-origin experiences and personality disorder characteristics are considered risk factors in relation to intimate partner violence. The present study's objective is to examine the predictive power of experiences in the family of origin and of pathological personality traits with respect to intimate partner violence, committed and suffered. Our sample consisted of 170 heterosexual couples from the metropolitan region of Porto Alegre, who answered the following questionnaires: Clinical Dimensional Personality Assessment (CDPA), Family Background Questionnaire, and Revised Conflict Tactics Scale (CTS2). The stepwise method of multiple linear regression analysis was employed. Our findings identified the "mood instability" and "impulsiveness" personality traits as predictors of violence committed by women; the "paternal physical abuse" and "aggressiveness" factors as predictors of violence committed by men; the "distrust" and "maternal decision-making approach" factors as predictors of violence suffered by women; and the "sexual abuse," "social avoidance" and "paternal psychological adjustment" factors as predictors of violence suffered by men. Only the individuals' traits displayed connections with intimate partner violence; none of the traits of the individuals' spouses exhibited a correlation. The study's results have implications for future research, indicating the existence of different explanatory models for men and women.
\end{abstract}

Keywords: Intimate partner violence, personality disorders, family of origin, child abuse.

\section{Violência Conjugal: O Poder Preditivo das Experiências na Família de Origem e das Características Patológicas da Personalidade}

\section{Resumo}

Experiências na família de origem e características dos transtornos da personalidade são apontadas como fatores de risco para a violência conjugal. Este estudo tem como objetivo investigar o poder

* Mailing address: Universidade do Vale do Rio dos Sinos, Centro de Ciências da Saúde, Avenida Unisinos, Cristo Rei, São Leopoldo, RS, Brazil 93022-750. Phone: (51) 99519-0801. E-mail: marcelamadalena@ hotmail.com, lucas@labape.com.br and dfalcke@unisinos.br 
preditivo das experiências na família de origem e das características patológicas da personalidade para a violência conjugal, cometida e sofrida. A amostra foi constituída por 170 casais heterossexuais da região metropolitana de Porto Alegre. Os participantes responderam aos seguintes instrumentos: Inventário Dimensional Clínico da Personalidade (IDCP), Family Background Questionnaire e a Revised Conflict Tactics Scale (CTS2). Foi realizada análise de regressão linear múltipla, através do método stepwise. Os resultados apontaram a Instabilidade de Humor e a Impulsividade como preditoras da violência cometida pelas mulheres; o Abuso Físico paterno e a Agressividade como preditores da violência cometida pelos homens; a Desconfiança e o Estilo de Decisão Materno como preditores da violência sofrida pelas mulheres; e o Abuso sexual, a Evitação Social e o Ajustamento Psicológico Paterno como preditores da violência sofrida pelos homens. Apenas características do indivíduo estiveram associadas à violência conjugal, nenhuma característica do parceiro apresentou correlação. Os dados do estudo possuem implicações para futuras pesquisas, sugerindo a existência de diferentes modelos explicativos da violência entre os sexos.

Palavras-chave: Violência conjugal, transtornos da personalidade, família de origem, maus-tratos infantil.

\section{La Violencia Conyugal: El Poder Predictivo de las Experiencias en la Familia de Origen y de las Características Patológicas de la Personalidad}

\section{Resumen}

Experiencias en la familia de origen y las características de los trastornos de personalidad se identifican como factores de riesgo para la violencia doméstica. Este estudio tiene como objetivo investigar la capacidad de predicción de experiencias en la familia de origen y las características patológicas de la personalidad a la violencia conyugal, cometidas y recibidas. La muestra fue de 170 parejas heterosexuales en la región metropolitana de Porto Alegre. Los participantes respondieron a los siguientes instrumentos: Inventario de Personalidad Clínica (PICD), Cuestionario de antecedentes familiares y tácticas de conflicto revisadas escala dimensional (CTS2). El análisis de regresión lineal múltiple se llevó a cabo mediante el método por etapas. Los resultados mostraron que la inestabilidad del humor y la impulsividad como predictores de violencia cometidos por las mujeres; Abuso físico paterna y la agresividad como predictores de violencia cometidos por los hombres; La desconfianza y el estilo materno Decisión como predictores de la violencia sufrida por las mujeres; y el abuso sexual, la evitación social y ajuste psicológico Paterno como predictores de la violencia que sufren los hombres. Sólo las características individuales se asociaron con la violencia doméstica, ninguna característica socio correlacionada. Los datos del estudio tienen implicaciones para la investigación futura, lo que sugiere la existencia de diferentes modelos explicativos de la violencia entre los sexos.

Palabras clave: Violencia doméstica, trastornos de la personalidad, familia de origen, maltrato infantil.

Intimate partner violence is a matter of social concern because of its impact on public health in Brazil and around the world (Ministry of Health, 2008; Vives-Cases, Álvarez-Dardet, \& Caballero, 2003). With respect to the perpetration of violence, meta-analyses indicate the existence of gender symmetry (Stith et al., 2000;
Straus, 2011), in contradiction of the viewpoint advocated by feminist studies to the effect that women are the principal victims (Johnson, 2006; Kelly \& Johnson, 2008). Nonetheless, it is noteworthy that, notwithstanding the existence of gender symmetry in terms of the perpetration of violence, the consequences are asymmetric, giv- 
en that violence perpetrated by men can be more injurious than violence committed by women can (Straus, 2011).

Aiming at comprehending violent behavior in relationships, many studies examine variables that are potentially associated with the phenomenon. Among them, adverse childhood incidents experienced in the family of origin are the risk factors most frequently studied (Fang \& Corso, 2007, 2008; Fehringer \& Hindin, 2009; Fergusson, 2011; Godbout, Dutton, Lussier, \& Sabourin, 2009; Jaoko, 2010; Wareham, Boots, \& Chavez, 2009; Yoshihma \& Horrocks, 2010). As per Stith and collaborators (2000), witnessing or suffering violent behavior within the familial environment as a child is related to experiencing intimate partner violence as an adult, both as a victim and as a perpetrator.

Generally speaking, adverse childhood experiences include physical, sexual, and emotional abuse, neglect (Ministry of Health, 2008), and psychoactive substance abuse on the part of parents (Fergusson, Boden, \& Horwood, 2008). Among such experiences, incidents involving abuse are studied the most. Several studies have transformed estimates of physical, sexual and emotional abuse into a single, general measurement of adverse childhood experiences and have linked this variable to the perpetration of intimate partner violence (Jin, Doukas, Beiting, \& Viksman, 2014; Mair, Cunradi, \& Todd, 2012; McKinney, Caetano, Ramisetty-Mikler, \& Nelson, 2009; Roberts, McLaughlin, Conron, \& Koenen, 2011). Specifically pinpointing each particular incident of abuse during childhood, other studies have revealed connections that are more specific, yet controversial. They spotted connections between parental physical, sexual and drug-related abuse in childhood and the perpetration of intimate partner violence in adulthood (Fergusson et al., 2008). Nevertheless, several authors have classified physical abuse as the principal predictor of the perpetration of violence (Fergusson et al., 2008), while others have included neglect alongside physical abuse as the key predictor (Fang \& Corso, 2008). In contrast, another study attributed greater predictive power to sexual abuse in terms of foreseeing the perpetration of violence (Fang \& Corso, 2007). Considering the connections with the intimate partner violence that was suffered, one observes differences between the findings of such studies, such as parental drug abuse and the perpetration of crimes (Fergusson et al., 2008), victimization via physical and sexual abuse (Afifi et al., 2009), and victimization by way of physical abuse and neglect (Widom, Czaja, \& Dutton, 2008).

Connections between adverse childhood experiences and intimate partner violence were identified for both men and women (Afifi et al., 2009; Fergusson et al., 2008; Hines, 2008; McKinney et al., 2009; White \& Widom, 2003), yet their impact could be different for each sex. The findings of various studies indicate that adverse childhood experiences in the family of origin can affect men more than they affect women. Furthermore, one observes the possibility of a direct connection between such experiences and intimate partner violence in the case of men. (Fergusson, 2011; Jin et al., 2014). Here, "direct connection" refers to the inexistence of other variables influencing the connection, whereas "indirect connection" would denote the existence of such variables. Such a direct relationship was discerned in a study by O'Leary, Slep and O'Leary (2007). By way of structural equation modeling, these authors perceived that adverse childhood experiences in the family of origin exhibit a direct connection with the perpetration of violence by men. In contrast, with respect to abuse committed by women, this correlation is indirect, i.e., it is influenced by other variables.

Nevertheless, the results of the studies reveal that the existence of adverse experiences in the family of origin is not a determining factor for the pattern to repeat itself in adulthood (Fang \& Corso, 2007, 2008; Fehringer \& Hindin, 2009; Fergusson, 2011; Godbout et al., 2009; Jaoko, 2010; Wareham et al., 2009; Yoshihma \& Horrocks, 2010). Several studies examine variables that mediate this connection; such variables include personality disorder characteristics (Liu et al., 2012; O’Leary et al., 2007), which are fre- 
quently analyzed from the standpoint of being related to violence between intimate partners (Costa \& Babcock, 2008; Ehrensaft, Cohen, \& Johnson, 2006; Fowler \& Westen, 2011; Holtzworth-Munroe, Meehan, Herron, Rehman, \& Stuart, 2003; Liu et al., 2012; Maneta, Cohen, \& Schulz, 2013; Thornton, Graham-Kevan, \& Archer, 2010).

Personality disorders are characterized by a strict pattern in at least two of the following areas: (a) affection; (b) cognition; (c) pattern of interpersonal relationships; and (d) impulse control. Such characteristics entail clinically significant suffering by and harm to the individual (American Psychological Association [APA], 2014). According to DSM-5, there are ten types of personality disorder (PD), which are labeled Paranoid, Schizoid, Schizotypal, Borderline, Antisocial, Histrionic, Narcissistic, Dependent, Obsessive-Compulsive and Avoidant (APA, 2014).

Borderline and antisocial PD traits appear with greater frequency in the literature (Costa \& Babcock, 2008; Fowler \& Westen, 2011; Holtzworth-Munroe et al., 2003; Liu et al., 2012; Maneta et al., 2013; Pico-Alfonso, Echeburúa, \& Martinez, 2008; Ross \& Babcock, 2009; Walsh et al., 2010; Weinstein, Oltmans, \& Gleason, 2012); and they also are observed to make up the typologies of intimate partner offenders. Nonetheless, the schizoid, schizotypal and paranoid types of PD of Cluster A (Ehrensaft et al., 2006; Thornton et al., 2010) and obsessive-compulsive PD of Cluster C (Fernández-Montalvo \& Echeburúa, 2008) were also found to be associated with intimate partner violence. Even so, obsessive-compulsive personality disorder should be examined with caution because it evidences controversies among the studies, also having been identified as protective in relation to such situations (Ehrensaft et al., 2006; Thornton et al., 2010).

Although only a few studies have yet examined personality disorder traits in relation to the abuse suffered, they did identify connections. Their findings indicate Cluster-A disorders (Pico-Alfonso et al., 2008) and borderline and anti- social PD (Kuijpers, Knaap, Winkel, Pemberton, $\&$ Baldry, 2010; Walsh et al., 2010).

Moreover, several studies have highlighted the analysis of the wife-husband dyad in situations involving marital violence (Bouchard, Sabourin, Lussier, \& Villeneuve, 2009; Langhinrichsen-Rohling, 2010; Maneta et al., 2013). After all, people involved in dyadic relationships can influence each other's thoughts, emotions and behaviors, a mechanism known as the partner effect (Kenny, Kashy, \& Cook, 2006).

In light of the aforementioned factors, one can see that intimate partner violence is a complex, multi-determined phenomenon. Along these lines, the present study aims to examine the predictive power of family-of-origin experiences and of spouses' pathological personality traits in relation to the incidence of marital violence, which is committed and suffered by both sexes.

\section{Method}

\section{Study Description}

The present research is a quantitative, cross-sectional study featuring an explanatory design, for it aims to identify variables that contribute to the incidence of the marital violence phenomenon.

\section{Sample}

This study's sample involved 170 heterosexual couples, residents of the metropolitan region of Porto Alegre (Brazil), between the ages of 19 and 81 years $(m=40.61 ; S D=12.74)$. The lengths of their relationships varied between six months and 56 years $(m=15.18 ; S D=11.82)$. In order to qualify for participation in the study, the couples had to be involved in a loving relationship and cohabiting. We established the following exclusion criteria: couples who had been living together for less than six months and individuals who had insufficient schooling to be able to comprehend and complete the surveys, which were self-administered questionnaires. The description of the sample is displayed in Table 1. 
Table 1

Description of the Sample

\begin{tabular}{ccc}
\hline Variables & & $\%$ \\
\hline Marital status & Officially married & $60.9 \%$ \\
& Living together & $39.1 \%$ \\
Prior cohabitation & Yes & $19.0 \%$ \\
& No & $81.0 \%$ \\
Children & Yes & $68.2 \%$ \\
Engages in paid & No & $31.8 \%$ \\
activity & Yes & $86.0 \%$ \\
Education & No & $14.0 \%$ \\
& No schooling & $0.60 \%$ \\
& Elementary school & $9.10 \%$ \\
& High school & $50.80 \%$ \\
& University & $39.50 \%$ \\
\hline
\end{tabular}

\section{Instruments}

The survey consisted of the following instruments:

Sociodemographic Data Questionnaire: 23 questions involving information such as age, education, occupation, income, length of the relationship and other items.

Family Background Questionnaire (FBQ) Subscales: the FBQ (Melchert, 1998a, 1998b) is an instrument that consists of questions related to 179 items, which are answered according to a five-point Likert scale. It features 15 subscales concerning the subject's recollections of incidents experienced in the family of origin. The present study employed the following subscales: maternal and paternal physical neglect; maternal and paternal physical abuse; sexual abuse; maternal and paternal drug abuse; psychological adjustment of the parents; and maternal and paternal decision-making approach. The FBQ was translated into Portuguese by Falcke (2003). It achieved high reliability indexes: 0.9902 for the overall scale; and between 0.40 and 0.95 for the subscales. In the present study, we obtained the following Cronbach's alphas for each subscale: physical neglect (0.616); paternal physical abuse (0.848); maternal physical abuse (0.781); sexual abuse (0.307); paternal drug abuse (0.939); maternal drug abuse (0.875); paternal psychological adjustment (0.589); maternal psychological adjustment (0.514); paternal decision-making approach (0.811); and maternal decision-making approach (0.798).

Clinical Dimensional Personality Assessment - CDPA (Carvalho, 2011): assesses pathological personality traits. DSM-IV Axis II symptoms and Millon's (2011; Millon, Grossman, Millon, Meagher, \& Ramnath, 2004) theory of personality disorders support the CDPA, which consists of 215 items in the form of questions that are answered according to a four-point Likert scale. The CDPA items are grouped into twelve subscales, which correspond to personality traits and can be indicators of personality disorders. In the present research, we found the following Cronbach's alphas for each subscale: dependency (0.857); aggressiveness (0.878); mood instability (0.920); eccentricity (0.862); need for attention (0.810); distrust (0.818); grandiosity (0.771); detachment (0.796); social avoidance (0.783); conscientiousness (0.684); and impulsiveness (0.675).

Revised Conflict Tactics Scales - CTS2 (Straus, Hamby, Boney-Mccoy, \& Sugarman, 1996; translated into Portuguese by Moraes, Hasselmann, \& Reichenheim, 2002): CTS2 consists of 78 questions that are answered according to a Likert scale. It rates minor and grave sexual coercion, minor and grave physical violence, minor and grave bodily injury, minor and grave psychological hostility, and negotiation. The answers encompass both the violent acts committed by those responding to the questionnaire and their views concerning their intimate partners' acts. In the present study, we employed the dimensions of minor and grave physical violence as an overall measurement of violence. The Cronbach's alpha we obtained for the global measurement of the physical violence committed was 0.997 ; and for that of the physical violence suffered, 0.998 . 


\section{Data Collection Procedures}

We chose the couples for the survey by way of convenience sampling. We then contacted them by phone to schedule the interviews at their homes, according to their availability. They answered the questionnaires in the presence of the researcher or a research assistant in a single session of 60 to 90 minutes.

\section{Ethical Considerations}

The present study is part of a broader study entitled "Variables Predictive of Marital Violence: Experiences in the family of origin; personal and interpersonal traits," which was submitted to the Research Ethics Committee of the University of Vale do Rio dos Sinos (UNISINOS) and approved by the same via Resolution No. 09/117. It thus complies with the ethical guidelines set forth in both Brazilian Health Council Resolution No. 466/2012 and Federal Psychology Council Resolution No. 026/2000. Survey participants signed an Informed Consent Form (TCLE, in Portuguese) authorizing the use of their information in the study. They were informed both as to the confidentiality of their identities and with regard to their option to freely abstain from participating at any time, without prejudice. Participants exhibiting signs of intimate partner violence were directed to the university's school of clinical medicine.

\section{Data Analysis Procedures}

The data was analyzed with IBM SPSS Statistics software (version 20.0). At first, we conducted descriptive analyses of the CTS2 estimates of the physical violence perpetrated and endured by the men and women in the sample. The dimensions of minor and grave physical violence were transformed into a single measurement of violence.

Three different versions of the Clinical Dimensional Personality Assessment (CDPA) were administered, in such a manner that survey participants filled out either the complete version $(n=146)$ or the reduced versions, A $(n=122)$ and $\mathrm{B}(n=72)$. In order to make it possible to obtain complete-version data for all of the par- ticipants, the information was initially analyzed via Winsteps psychometric software, which is based on the Rasch item response theory (IRT) model. In this manner, the indices of difficulty (b) of the items were determined based on the data from the normative group. The data was entered separately by factor, resulting in theta values (latent trait levels) for each participant in all dimensions. Accordingly, all analyses that involved the CDPA were conducted using such theta values.

The next step was to perform a Pearson correlation analysis to test the correlation between the CDPA factors and the FBQ subscales using the CTS2 measurements of physical violence (committed and suffered). Analyses were conducted separately for men and women. Subsequently, the database was rearranged into pairs so as to examine the connection between the CDPA factors and the FBQ subscales of the wives with the husbands' CTS2 violence measurements, and vice versa.

Based on the findings of our correlation analyses, we chose the variables to be employed in the multiple linear regression analyses. Accordingly, only those variables that exhibited a substantial connection with the measurements of physical violence committed and suffered by men and women were included as independent variables in the models. We selected the stepwise regression analysis method, a method that adapts the model by way of including significant variables and removing insignificant variables (Hair, Anderson, Tatham, \& Black, 2005).

\section{Results}

By way of descriptive analysis, we identified the frequencies of physical violence committed and suffered by men and women. The results are displayed in Figure 1. As per such data, no significant statistical difference between the sexes was observed in the CTS2 measurements $\left(\mathrm{x}^{2}=1.859 ; d f=1 ; p=.173\right)$. 


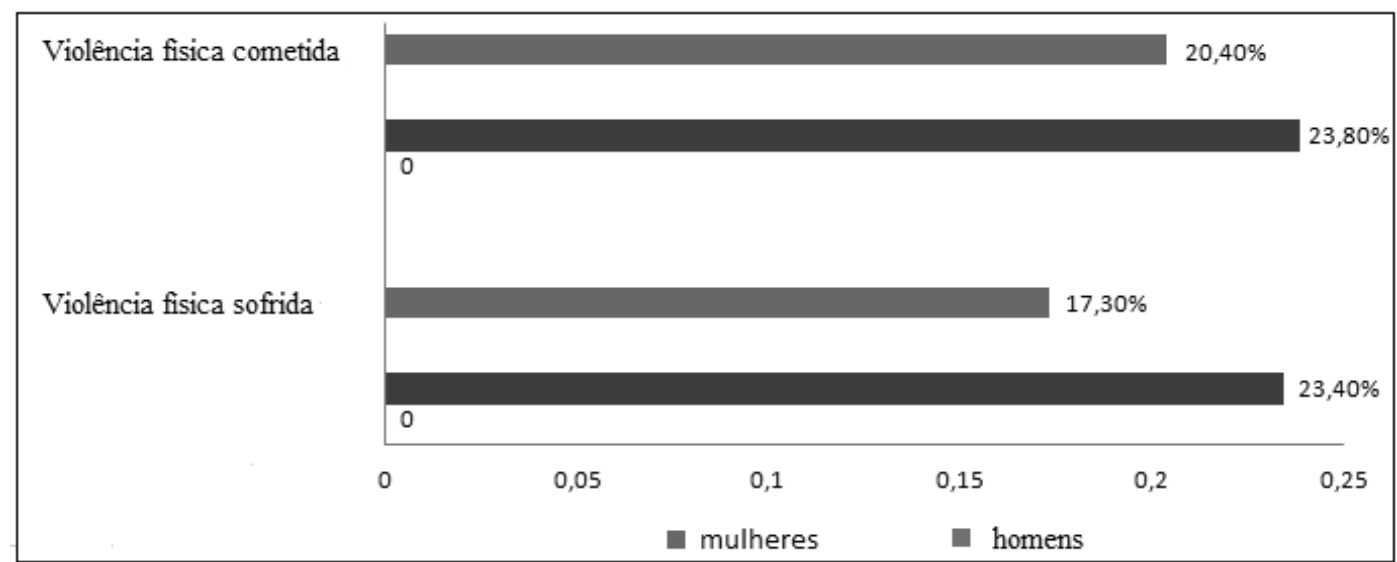

Figure 1. Frequencies of physical violence committed and suffered by men and women.

Table 2

Matrix of Correlations between Physical Violence Committed and Suffered by Women and Men in Relation to Personality Traits and Experiences in the Family of Origin

\begin{tabular}{|c|c|c|c|c|}
\hline & \multicolumn{2}{|c|}{ Physical Violence Committed } & \multicolumn{2}{|c|}{ Physical Violence Suffered } \\
\hline & Women & Men & Women & Men \\
\hline Dependency & 0.092 & 0.150 & 0.069 & $0.187^{*}$ \\
\hline Aggressiveness & $0.194 *$ & $0.264 * *$ & $0.203^{* *}$ & $0.225^{* *}$ \\
\hline Mood instability & $0.244^{* *}$ & $0.173^{*}$ & $0.232 * *$ & $0.188^{*}$ \\
\hline Eccentricity & $0.212 *$ & $0.174^{*}$ & $0.223 * *$ & $0.171^{*}$ \\
\hline Need for attention & 0.061 & 0.046 & 0.117 & 0.063 \\
\hline Distrust & $0.243^{* *}$ & 0.074 & $0.304^{* *}$ & 0.117 \\
\hline Grandiosity & $0.221^{* *}$ & $0.179^{*}$ & $0.207^{* *}$ & $0.181^{*}$ \\
\hline Detachment & 0.151 & 0.153 & $0.266^{* *}$ & $0.165^{*}$ \\
\hline Social avoidance & 0.104 & $0.244 * *$ & 0.110 & $0.265^{* *}$ \\
\hline Self-sacrifice & 0.034 & 0.042 & 0.094 & 0.035 \\
\hline Conscientiousness & 0.037 & 0.019 & 0.084 & 0.006 \\
\hline Impulsiveness & $0.210^{* *}$ & $0.164^{*}$ & $0.246^{* *}$ & 0.136 \\
\hline Paternal physical abuse & 0.119 & $0.227 * *$ & -0.025 & $-0.206^{*}$ \\
\hline Maternal physical abuse & $0.191^{*}$ & 0.137 & -0.138 & -0.101 \\
\hline Sexual abuse & $0.264 * *$ & $0.170^{*}$ & $0.174 *$ & $0.300^{* *}$ \\
\hline Physical neglect & 0.074 & $0.175^{*}$ & 0.043 & -0.006 \\
\hline Paternal decision-making & -0.034 & -0.127 & -0.156 & -0.064 \\
\hline Maternal decision-making & -0.098 & -0.133 & $-0.227 * *$ & 0.015 \\
\hline Paternal substance abuse & 0.028 & 0.101 & 0.078 & -0.075 \\
\hline Maternal substance abuse & $0.220^{*}$ & 0.028 & -0.128 & -0.048 \\
\hline Paternal psychol. adjustment & -0.116 & $-0.294 * *$ & -0.079 & $-0.291 * *$ \\
\hline Maternal psychol. adjustment & $-0.199^{*}$ & -0.11 & $-0.263 * *$ & -0.065 \\
\hline Family ties & -0.151 & -0.081 & -0.11 & -0.032 \\
\hline
\end{tabular}

$* p<.05 ; * * p<.001$ 
Employing the paired database, we ran a Pearson correlation analysis to verify the connection between the pathological traits of the husbands' personalities and the dimensions of physical violence of the wives. The same procedure was also employed with respect to the wives' personality disorders and the husbands' dimensions of physical violence. As per the findings, no noteworthy connections between the variables were observed $(p>.05)$.

We then ran a correlation analysis of the unpaired database to discover which variables would be included in the regression model. Table 2 displays the correlation data.

All of the connections we detected were weak, yet statistically significant and thus sup- portive of regression analysis. The reason for employing the stepwise multiple-regressionanalysis method was to assess the predictive power of both pathological personality traits and experiences in the family of origin with respect to the physical violence committed and suffered by the men and women of the sample. Accordingly, only variables that exhibited a significant connection with physical violence were included in the analysis. Four independent analyses were conducted considering the four different outcomes: physical violence committed by women, physical violence committed by men (Table 3 ), physical violence suffered by women and physical violence suffered by men (Table 4).

Table 3

Predictors of Physical Violence Committed by Women and Men

\begin{tabular}{|c|c|c|c|c|c|}
\hline \multirow[b]{3}{*}{ Predictors } & \multicolumn{3}{|c|}{ Women } & \multirow[b]{3}{*}{$t$} & \multirow[b]{3}{*}{ Sig. } \\
\hline & \multicolumn{2}{|c|}{$\begin{array}{l}\text { Non-standardized } \\
\text { coefficients }\end{array}$} & \multirow{2}{*}{$\begin{array}{c}\begin{array}{c}\text { Standardized } \\
\text { coefficients }\end{array} \\
\text { Beta }\end{array}$} & & \\
\hline & $B$ & Std. Error & & & \\
\hline (Constant) & 14.255 & 0.439 & & 32.437 & 0.000 \\
\hline Mood instability & 0.532 & 0.195 & 0.293 & 2.719 & 0.008 \\
\hline \multirow[t]{4}{*}{ Impulsiveness } & 0.391 & 0.185 & 0.228 & 2.119 & 0.037 \\
\hline & \multicolumn{3}{|c|}{$R=0.436 ; R^{2}=0.190 ; R_{\text {adjusted }}^{2}=0.170$} & & \\
\hline & \multicolumn{3}{|c|}{ Men } & & \\
\hline & \multicolumn{2}{|c|}{$\begin{array}{l}\text { Non-standardized } \\
\text { coefficients }\end{array}$} & $\begin{array}{l}\text { Standardized } \\
\text { coefficients }\end{array}$ & & \\
\hline Predictors & $B$ & Std. Error & Beta & $t$ & Sig. \\
\hline (Constant) & 14.07 & 0.468 & & 30.033 & 0.00 \\
\hline Paternal physical abuse & 0.136 & 0.059 & 0.232 & 2.296 & 0.024 \\
\hline \multirow[t]{2}{*}{ Aggressiveness } & 0.26 & 0.129 & 0.204 & 2.022 & 0.046 \\
\hline & \multicolumn{3}{|c|}{$R=0.344 ; R^{2}=0.118 ; R_{\text {adjusted }}^{2}=0.099$} & & \\
\hline
\end{tabular}

One observes that the "mood instability" and "impulsiveness" variables are the final female model's predictors; together, they explain $19 \%$ of the variance of the physical violence committed by the women in the sample. The correlation between the independent variables and the model's criterion is moderate $(R=0.43)$. The standardized coefficients of the regression analysis reveal that the "mood instability" personality trait $(\beta=0.293 ; p=.008)$ is the model's strongest predictive variable. The "mood instability" and "impulsiveness" personality traits are 
positively associated with the physical violence committed by the women.

With respect to the physical violence committed by the men in the sample, the "paternal physical abuse" and "aggressiveness" variables are the final male model's predictors, explaining $11.8 \%$ of the variance. The standardized coefficients of the regression analysis reveal that paternal physical abuse $(\beta=232 ; p=.024)$ is the strongest variable, followed by aggressiveness $(\beta=204 ; p=.046)$.

Table 4

Predictors of Physical Violence Suffered by Women and Men

\begin{tabular}{|c|c|c|c|c|c|}
\hline \multirow[b]{3}{*}{ Predictors } & \multicolumn{3}{|c|}{ Women } & & \\
\hline & \multicolumn{2}{|c|}{ Non-standardized coefficients } & \multicolumn{3}{|l|}{$\begin{array}{l}\text { Standardized } \\
\text { coefficients }\end{array}$} \\
\hline & $B$ & Std. Error & Beta & $T$ & Sig. \\
\hline (Constant) & 14.727 & 0.555 & & 26.534 & 0.00 \\
\hline Distrust & 0.447 & 0.113 & 0.322 & 3.945 & 0.00 \\
\hline \multirow[t]{4}{*}{ Maternal decisions } & -0.047 & 0.016 & -0.246 & -3.005 & 0.003 \\
\hline & \multicolumn{5}{|c|}{$R=0.427 ; R^{2}=0.183 ; R_{\text {adjusted }}^{2}=0.169$} \\
\hline & \multicolumn{3}{|c|}{ Men } & & \\
\hline & \multicolumn{2}{|c|}{$\begin{array}{l}\text { Non-standardized } \\
\text { coefficients }\end{array}$} & $\begin{array}{l}\text { Standardized } \\
\text { coefficients }\end{array}$ & & \\
\hline Predictors & $B$ & Std. Error & Beta & $t$ & Sig. \\
\hline (Constant) & 27.337 & 16.432 & & -1.664 & 0.1 \\
\hline Sexual abuse & 2.316 & 0.782 & 0.282 & 2.961 & 0.004 \\
\hline Social avoidance & 0.502 & 0.239 & 0.203 & 2.103 & 0.038 \\
\hline \multirow[t]{2}{*}{ Paternal psychol. adj. } & -0.119 & 0.059 & -0.197 & -2.001 & 0.048 \\
\hline & \multicolumn{3}{|c|}{$R=0.468 ; R^{2}=0.219 ; R_{\text {adjusted }}^{2}=0.193$} & & \\
\hline
\end{tabular}

Our findings reveal that the "distrust" and "maternal decision-making approach" variables are the final female model's predictors; together, they explain $18.3 \%$ of the variance of the physical violence suffered by the women in the sample. The standardized coefficients of the regression analysis show that the "distrust" personality trait ( $\beta=0.322 ; p=.001)$ explains the greater part of the model, being supplemented by the "maternal decision-making approach" variable $(\beta=-0.246$; $p=.003)$. The "distrust" variable is positively associated with physical violence, whereas the "maternal decision-making approach" variable is negative, revealing that the higher the score on this scale, the less violence.
With respect to the dependent variable, "physical violence suffered by men," one observes that the "sexual abuse," "social avoidance" and "paternal psychological adjustment" variables are the final model's predictors, explaining $21.9 \%$ of the variance. The standardized coefficients of the regression analysis reveal that sexual abuse $(\beta=0.282, p=.004)$ is the strongest variable, followed by social avoidance $(\beta=0.203 ; p=.038)$ and paternal psychological adjustment $(\beta=-0.197 ; p=.048)$. The sexual abuse and social avoidance variables are positively related to physical violence, while the paternal psychological adjustment variable exhibits a negative correlation, which indicates its 
preventive nature in relation to the incidence of violence.

\section{Discussion}

The present study's aim was to assess the predictive power of pathological personality traits and of family-of-origin experiences with respect to the following four distinct outcomes: physical violence committed by women, physical violence committed by men, physical violence suffered by women and physical violence suffered by men. At the outset, we conducted descriptive analysis of the data related to physical violence. Our findings indicate no noteworthy discrepancies between men and women with respect to committing or suffering physical violence. Such a finding evidences the fact that, in relation to the sample, the gender variable was not a determining factor for explaining the phenomenon, contrary to what has been observed in prior studies (Stith et al., 2000; Straus, 2011).

As per our findings, we pinpointed mood instability, aggressiveness and impulsiveness as the pathological personality traits that predict the perpetration of marital violence. It is worth mentioning that such traits do not amount to personality disorders. Nonetheless, each trait relates more to the characteristics of certain disorders than it does to those of others (Carvalho, 2011). Accordingly, during the course of the present article, we point out the connections between the pathological personality traits assessed in the CDPA and the personality disorder characteristics analyzed in other studies.

The "mood instability," "aggressiveness" and "impulsiveness" personality traits are associated with the characteristics of borderline and antisocial personality disorders (PDs), which are frequently identified as being related to intimate partner violence (Fowler \& Westen, 2011; Ross, 2011; Ross \& Babcock, 2009; Whisman \& Schonbrun, 2009). The "mood instability" personality trait applies to individuals tending toward sad or irritable moods and fluctuations in their temperaments and beliefs, exhibiting impulsive and radical reactions. Such traits are also characteristics of borderline personality disorder
(Carvalho, 2011). The "aggressiveness" trait is associated with people who are disregardful of others in order to get what they want, are incoherent and are usually violent; whereas the "impulsiveness" trait relates to individuals who exhibit impetuous reactions, a fondness for violent activities, a knack for inventing excuses and a tendency toward getting into trouble (Carvalho, 2011). The latter two traits (aggressiveness and impulsiveness) evidence characteristics of antisocial personality disorder (APA, 2014).

Other pathological personality traits were once also presumed to explain the perpetration of marital violence, yet this presumption was never substantiated. In light of this fact, the present study's findings corroborate the results of the majority of the studies concerning violent partners (Askeland \& Heir, 2014; Jose, O’Leary, Gomez, \& Foran, 2014; Maneta et al., 2013; Reingle, Jennings, Connell, Businelle, \& Chartier, 2014; Thomas, Bennett, \& Stoops, 2013). Furthermore, the personality trait most predictive of women's violent acts, mood instability, is more closely tied to borderline personality disorder; and the trait most predictive of male violence, aggressiveness, is more strongly associated with antisocial PD. The same predictors for men and women were also identified in Ross and Babcock's study of violent partners (2009). Along the same lines, research conducted by Weinstein et al. (2012) revealed that the characteristics of borderline PD in women were stronger predictors of intimate partner violence than they were in the case of men. This could be related to the fact that borderline disorder is three times more common in women than it is in men (APA, 2014).

In addition to such gender asymmetries, we spotted other differences between the sexes. In contrast to the results obtained for men, no experience in the family of origin was observed in the final model of violence perpetrated by women. This fact could imply that adverse experiences in the family of origin have a lesser impact on women's conjugality, in contrast to what is evidenced in the literature (Fergusson et al., 2008). Another option would be to consider that the connection between adverse experiences in 
the family of origin and violence committed by women could be indirect, as was stated in a study conducted by O'Leary et al. (2007). Employing structural equation modeling, the authors discovered an indirect connection between adverse experiences in the family of origin and violence committed by women. One can comprehend such an indirect connection when observing both that adverse domestic childhood experiences are considered part of the etiological variables involved in the development of borderline personality disorder [BPD] (Cohen et al., 2014; Laporte, Jiang, Pepler, \& Chamberland, 2011) and that the "mood instability" trait exhibits BPD characteristics. This hypothesis is thus coherent and is in agreement with a study conducted by Liu and collaborators (2012) that discerned BPD characteristics that partially mediate the relationship between childhood abuse experiences and the perpetration of marital violence.

Such data contributes to the discussion of violence committed by women. The following issue frequently arises: Do women commit violent acts against their partners for the purpose of self-defense or for psychopathological reasons, as previously identified in the case of men (Ross \& Babcock, 2009)? The present study demonstrates the importance of the fact that pathological personality traits partially explain such behavior.

With respect to the impulsiveness trait, which was also identified as a predictor of violence committed by women, one observes that it exhibits characteristics that are most closely tied to antisocial personality disorder (APA, 2014). This information surprised us in light of the fact that borderline PD characteristics are the most closely related to violence perpetrated by women (Ross \& Babcock, 2009; Weinstein et al., 2012). Even so, one must bear in mind that the impulsiveness trait exhibited less strength than that of mood instability in terms of predicting violence committed by women.

In the present study, the physical violence committed by men was explained by the pathological personality trait of aggressiveness and by paternal physical abuse, which was the strongest variable. This fact is in agreement with the litera- ture that identifies abusive childhood experiences as predictors of marital violence committed by men (Fang \& Corso, 2007, 2008; Fergusson et al., 2008), capable of explaining such behavior better than other variables do (Jin et al., 2014). Such a finding is consonant with authors who pinpoint physical abuse as the principal predictor (Alexander, Moore, \& Alexander, 1991; Fergusson et al., 2008) and is contrary to those who point to sexual abuse (Fang \& Corso, 2007, 2008).

What one observes with greater frequency in the literature is the fact that adverse experiences in the family of origin have a greater impact on men's behavior than on women's behavior (Fergusson et al., 2008). The connection between these variables is mentioned by social learning theory, which views this issue in terms of children's imitation of their role models' behaviors (Bandura, Ross, \& Ross, 1963). In the case of violence, it can be considered a problem-solving strategy. From this standpoint, the model's gender is a factor that contributes to such imitation; it is thus important to consider the influence of gender roles on human development. In the present study, this factor is viewed in terms of paternal physical abuse's impact on violence committed by men, in accordance with an earlier study (Alexander et al., 1991).

Despite the present study's findings being in line with the literature with respect to the fact that childhood abuse better explains violence perpetrated by men, it is intriguing that such gender differences exist. Why do such childhood experiences affect men more than they affect women? Which gender-related factors influence this observable fact? Such issues call for further research so as to expand our comprehension of the phenomenon. According to O'Leary et al. (2007), there is a direct connection between such variables in the case of men, while it is indirect with respect to women. Even so, how does this phenomenon take place? Falcke (2003) offered a plausible explanation, suggesting that women tend to evaluate their childhood experiences, which makes it possible for them to overcome certain aspects. In contrast, men tend to engage in such assessments much less frequently. With- 
out a doubt, such gender distinctions defy a linear or homogeneous conception of intimate partner violence.

Despite not exhibiting as much predictive power as physical abuse did, the aggressiveness personality trait was part of the final model of male-perpetrated violence. The predictive power of the aggressiveness trait, which displays attributes of antisocial personality disorder, had already been characterized in the literature as being connected with marital violence (Costa \& Babcock, 2008; Holtzworth-Munroe et al., 2000; Kivisto, Little, Moore, \& Rhatigan, 2011; Ross \& Babcock, 2009). It is one of the important characteristics of the "generally violent" offender subtype, which was categorized in Holtzworth-Munroe and Stuart's typology (1994).

Numerous issues undoubtedly still require clarification with respect to the connection between pathological personality traits and the perpetration of marital violence. Whisman and Schonbrun (2009) indicate the necessity of specifically identifying borderline personality traits that are associated with the perpetration of intimate partner violence. The same can said concerning antisocial personality traits.

Furthering the comprehension of the interpartner violence phenomenon, studies were conducted to examine the violence suffered by men and women, a factor previously uninvestigated in the research. Their findings identified both adverse experiences in the family of origin and pathological personality traits as predictors. The personality-trait factor was the strongest variable in the final female model; and in the male model, the adverse-experiences factor. These findings are analogous to those discerned in relation to violence perpetrated by men and women.

A predictor of the intimate partner violence suffered by women, the "distrust" trait refers to individuals who exhibit a persistent lack of ability to trust others for fear of their intentions, displaying what appears to be a persecution complex (Carvalho, 2011). Although this trait is observed in various types of personality disorder, it seems to be more closely related to paranoid PD. This observation is in agreement with a study conducted by Pico-Alfonso et al. (2008), concerning female victims of marital violence.

It is worth mentioning that, up to the present time, only a handful of studies have researched the characteristics of violence-related types of personality disorder (Kuijpers et al., 2010; Maneta et al., 2013; Reingle et al., 2014; Walsh et al., 2010). Furthermore, in a survey of the traits of personalities other than borderline and antisocial, we found only one study (Pico-Alfonso et al., 2008). This is a finding that needs to be better understood. Nonetheless, one can see that distrustful attitudes can influence a marital relationship, especially if such attitudes target the incredulous partner's spouse. Several authors consider trust an important variable for positive communication between spouses (Rempel, Ross, \& Holmes, 2001). We may thus consider the hypothesis that distrustful individuals are capable of influencing the violent behaviors of their spouses via the so-called partner effect.

With respect to the model that explains the violence suffered by women, the maternal decision-making approach factor is connected with the distrust trait, which exhibited a negative correlation with the violence suffered. This familyof-origin dimension relates both to the consistency of parents' attitudes toward their children and to their ability to understandingly listen to their kids, both of which contribute to an atmosphere of security, trust and stability (Melchert, 1998b). Such an atmosphere may thus be considered a shield against the violence suffered by women. It could also suggest that when our first childhood bonds offer security and approval, they contribute to establishing healthier marital relationships later in life. This was observed in a study conducted by Treboux, Crowell and Waters (2004), which revealed that individuals enjoying secure emotional bonds had better affectionate relationships and milder conflicts.

As to the model of violence suffered by men, one observes that sexual abuse was the adverse childhood experience with the greatest impact. This observation corroborates a study by Afifi and collaborators (2009), which spotted a connection between childhood sexual abuse and an increase in men's likelihood of becoming marital violence victims later on. In contrast to this 
finding, other studies have found that such experiences predict violence committed by childhood sexual abuse victims against their spouses in adulthood (Fang \& Corso, 2007, 2008). In light of such contrasting findings, is it even possible to make final conclusions? Being attentive of the impact of such experiences, especially on men, is of utmost importance in terms of dealing with such aspects in the treatment of child abuse victims and marital abusers. Together with the above data, paternal psychological adjustment proved to be a protective factor against violent incidents, demonstrating that a caregiver's emotional stability contributes to healthy development. As in the case of the results obtained in the female sample, one observes a model gender's importance with respect to individuals' behaviors.

The social avoidance trait was part of the men's final model, exhibiting less predictive power than sexual abuse did. It is associated with the avoidant, schizoid and schizotypal varieties of personality disorder, especially the former (Carvalho, 2011). Its characteristics include a generalized belief in one's own incapacity and a fear of being criticized or humiliated (Carvalho, 2011). This was also observed in a study by Pico-Alfonso et al. (2008), which revealed high avoidant-personality scale scores for marital violence victims. However, that study only surveyed women. Even so, we can still presume that the avoidant pathological personality trait causes husbands to be vulnerable to their wives' abusive behaviors. In light of the fact that a husband's fear of being criticized and his belief in his own incapacity can trigger conflict avoidant behavior on his part, his wife could interpret such an attitude as hostile conduct or as indifference toward solving marital problems. Nonetheless, this is still a premature notion that requires further investigation.

It is remarkable that we found no correlation between spouses' personality traits and intimate partner violence in the paired database. International studies had already detected correlations both between wives' and husbands' personality traits and between one spouse's personality traits and violence perpetrated by the other spouse
(Bouchard et al., 2009; Maneta et al., 2013). We believe we obtained no such results in the present study because we did not survey a clinical sample, which would have exhibited higher levels of psychopathology and even violence. We thus recommend that future studies consider such a survey in their research.

\section{Final Considerations}

The present study has implications in the debate on this subject. Our analyses were performed separately for men and women, for expanding the research method does not imply ignoring gender differences, which were in fact observed in this study. While women's violent acts were better explained by their pathological personality traits, men's violent acts were more influenced by their experiences in the family of origin. Such facts raise an important issue that requires further study and they underscore the need to view violence as a heterogeneous phenomenon. In light of the fact that only a few studies deal with pathological personality traits associated with violence suffered, our results and hypotheses support future research.

As to the perpetration of violence, our findings encourage us to recommend separate marital violence models for men and women, thereby making it possible to test them via structural equation modeling. With respect to the women's model, we believe that borderline personality disorder should be tested as to whether or not it is a variable that mediates the relationship between experiences in the family of origin and intimate partner violence. Regarding the male model, tests should be run as to whether or not antisocial personality disorder mediates the relationship between experiences in the family of origin and marital violence, that is, whether the relationship is indirect or direct.

The present study has its limitations. Among such shortcomings, what stands out is the fact that personality disorders were not quantified in this study (nonetheless, pathological personality traits were measured). Furthermore, neither the impact of the examinees' ages nor the influence of the lengths of their relationships 
was examined. We thus recommend that future studies take such variables into consideration. Moreover, our data was collected from a nonclinical sample, thus increasing the probability that such data encompasses incidents that are less violent than those observed in cases involving formal charges. With respect to adverse childhood experiences in the family of origin, one must take into consideration the fact that the instrument we employed is based on the examinees' memories, the survey being of a transversal nature. Nonetheless, the present research does contribute to this subject in the sense of providing support both for future studies of individuals involved in violent situations and for discussions concerning this theme, especially within the Brazilian context.

\section{References}

Afifi, T. O., MacMillan, H., Cox, B. J., Asmundson, G. J. G., Stein, M. B., \& Sareen, J. (2009). Mental health correlates of intimate partner violence in a nationally representative sample of males and females. The Journal of Interpersonal Violence, 24, 1398-1417. doi:10.1177/0886260508322192

Alexander, P. C., Moore, S., \& Alexander, E. R. (1991). What is transmitted in the inter-generational transmission of violence? Journal of Marriage and the Family, 53, 657-668. doi:10.2307/352741

American Psychological Association. (2014). Manual Diagnóstico e Estatístico de Transtornos Mentais - IV. Porto Alegre, RS: ArtMed.

Askeland, I. R., \& Heir, T. (2014). Psychiatric disorders among men voluntarily in treatment for violent behaviour: A cross-sectional study. BMJ Open, 4(4), 1-5. doi:10.1136/bmjopen-2013-004485

Bandura, A., Ross, D., \& Ross, S. A. (1963). Vicarious reinforcement and imitative learning. Journal of Abnormal and Social Psychology, 67(6), 601-607. Retrieved from https://www.ncbi.nlm. nih.gov/pubmed/14084769

Bouchard, S., Sabourin, S., Lussier, Y., \& Villeneuve, E. (2009). Relationship quality and stability in couples when one partner suffers from borderline personality disorder. Journal Marital Family Therapy, 35(4), 446-455. doi:10.1111/ j.1752-0606.2009.00151.x
Carvalho, L. F. (2011). Desenvolvimento e verificação das propriedades psicométricas do Inventário Dimensional Clínico da Personalidade (Doctoral dissertation, Programa de Pós-Graduação Strictu Sensu em Psicologia, Universidade São Francisco, São Paulo, SP, Brazil). Retrieved from https://www.usf.edu.br/galeria/ getImage/427/606165816189410.pdf

Cohen, L. J., Tanis, T., Bhattacharjee, R., Nesci, C., Halmi, W., \& Galynker, I. (2014). Are there differential relationships between different types of childhood maltreatment and different types of adult personality pathology? Psychiatry Research, 215(1), 192-201. doi:10.1016/j.psychres.2013.10.036

Costa, D., \& Babcock, J. C. (2008). Articulated thoughts of intimate partner abusive men during anger arousal: Correlates with personality disorder features. Journal of Family Violence, 23(6), 395-402. doi:10.1007/s10896-008-9163-x

Ehrensaft, M. K., Cohen, P., \& Johnson, J. G. (2006). Development of personality disorder symptoms and the risk for partner violence. Journal of Abnormal Psychology, 115(3), 474-483. doi:10.1037/0021-843X.115.3.474

Falcke, D (2003). Águas passadas não movem moinhos? As experiências na família de origem como preditoras da qualidade do relacionamento conjugal (Doctoral dissertation, Programa de PósGraduação em Psicologia, Pontifícia Universidade Católica do Rio Grande do Sul, Porto Alegre, RS, Brazil). Retrieved from http://www.scielo. $\mathrm{br} / \mathrm{scielo}$.php?script $=$ sci_nlinks\&pid=S0103$863 X 201400020017700014 \& \operatorname{lng}=\mathrm{en}$

Fang, X., \& Corso, P. S. (2007). Child maltreatment, youth violence, and intimate partner violence. American Journal of Preventive Medicine, 33(4), 281-290. doi:10.1016/j.amepre.2007.06.003

Fang, X., \& Corso, P. S. (2008). Gender differences in the connections between violence experienced as a child and perpetration of intimate partner violence in young adulthood. Journal of Family Violence, 23(5), 303-313. doi:10.1007/ s10896-008-9152-0

Fehringer, J. A., \& Hindin, M. J. (2009). Like parent, like child: Intergenerational transmission of partner violence in Cebu, the Philippines. Journal of Adolescent Health, 44(4), 363-371. doi:10.1016/j.jadohealth.2008.08.012

Fergusson, C. J. (2011). Love is a battlefield: Risk factors and gender disparities for domestic vio- 
lence among Mexican Americans. Journal of Aggression, Maltreatment \& Trauma, 20(2), 227-236. doi:10.1080/10926771.2011.546829

Fergusson, C. J., Boden, J. M., \& Horwood, L. J. (2008). Developmental antecedents of interpartner violence in a New Zealand Birth Cohort. Journal of Family Violence, 23, 737-753. doi:10.1007/s10896-008-9199-y

Fernández-Montalvo, J., \& Echeburúa, E. (2008). Trastornos de personalidad y psicopatía en hombres condenados por violencia grave contra la pareja. Psicothema, 20(2), 193-198. Retrieved from http://www.psicothema.com/psicothema. asp? $\mathrm{id}=3447$

Fowler, K. A., \& Westen, D. (2011). Subtyping male perpetrators of intimate partner violence. Journal of Interpersonal Violence, 26(4) 607-639. doi:10.1177/0886260510365853

Godbout, N., Dutton, D. G., Lussier, Y., \& Sabourin, S. (2009). Early exposure to violence, domestic violence, attachment representations, and marital adjustment. Personal Relationships, 16(3), 365384. doi:10.1111/j.1475-6811.2009.01228.x

Hair, J. F., Anderson, R. E., Tatham, R. L., \& Black, W. C. (2005). Análise multivariada de dados. Porto Alegre, RS: Bookman.

Holtzworth-Munroe, A., Meehan, J. C., Herron, K., Rehman, U., \& Stuart, G. L. (2003). Do subtypes of maritally violent men continue to differ over time? Journal of Consulting and Clinical Psychology, 71(4), 728-740. doi:10.1037/0022006X.71.4.728

Holtzworth-Munroe, A., \& Stuart, G. L. (1994). Typologies of male batterers: Three subtypes and the differences among them. Psychological Bulletin, 16(3), 476-497. doi:10.1037//00332909.116.3.476

Jaoko, J. (2010). Correlates of wife abuse in the Maseno and Nairobi areas of Kenya. International Social Work, 53(1), 9-18. doi:10.1177/0020872809348864

Jin, X., Doukas, A., Beiting, M., \& Viksman, A. (2014). Factors contributing to intimate partner violence among men in Kerala, India. Journal of Family Violence, 29(6), 643-668. doi:10.1007/ s10896-014-9623-4

Johnson, M. P. (2006). Conflict and control: Gender symmetry and asymmetry in domestic violence. Violence Against Women, 12(11), 1003-1018. doi:10.1177/1077801206293328
Jose, A., O’Leary, K. D., Gomez, J. L. G., \& Foran, H. M. (2014). Risk factors for men's intimate physical aggression in Spain. Journal of Family Violence, 29, 287-297. doi:http://dx. doi. org/10.1007/s10896-014-9589-2

Kelly, J. B., \& Johnson, M. P. (2008). Differentiation among types of intimate partner violence: Research update and implications for interventions. Family Court Review, 46(3), 476-499. doi:10.1111/j.1744-1617.2008.00215.x

Kenny, D. A., Kashy, D. A., \& Cook, W. L. (2006). Dyadic data analysis. New York: Guilford Press.

Kivisto, A. J., Little, K. C., Moore, T. M., \& Rhatigan, D. L. (2011). Antisociality and intimate partner violence: The facilitating role of shame. Violence and Victims, 26, 758-773.

Kuijpers, K., Knaap, L. M., Winkel, F. W., Pemberton, A., \& Baldry, A. C. (2010). Borderline traits and symptoms of post-traumatic stress in a sample of female victims of intimate partner violence. Stress and Health, 27(3), 206-215. doi:10.1002/smi.1331

Langhinrichsen-Rohling, J. (2010). Controversies involving gender and intimate partner violence in the United States. Sex Roles, 62(3-4), 179-193. doi:10.1007/s11199-009-9628-2

Laporte, L., Jiang, D., Pepler, D. J., \& Chamberland, C. (2011). The relationship between adolescents' experience of family violence and dating violence. Youth \& Society, 43(1), 3-27. doi:10.1177/0044118X09336631

Liu, N., Zhang, Y., Brady, H. J., Cao, Y., He, Y., \& Zhang, Y. (2012). Relation between childhood maltreatment and severe intrafamilial maleperpetrated physical violence in Chinese community: The mediating role of borderline and antisocial personality disorder features. Agressive Behavior, 38(1), 64-76. doi:10.1002/ ab.20417

Mair, C., Cunradi, C. B., \& Todd, M. (2012). Adverse childhood experiences and intimate partner violence: Testing psychosocial mediational pathways among couples. Annals of Epidemiology, $22,832-839$

Maneta, E. K., Cohen, S., \& Schulz, M. S. (2013). Two to Tango: A dyadic analysis of links between borderline personality traits and intimate partner violence. Journal of Personality Disorders, 27(2), 233-243. doi:10.1521/pedi.2013.27.2.233 
McKinney, C. M., Caetano, R., Ramisetty-Mikler, S., \& Nelson, S. (2009). Childhood family violence and perpetration and victimization of intimate partner violence: Findings from a national population-based study of couples. Annals of Epidemiology, 19(1), 25-32. doi:10.1016/j.annepidem.2008.08.008

Melchert, T. P. (1998a). A review of instruments for assessing family history. Clinical Psychology Review, 18, 163-187. doi:http://dx.doi. org/10.1016/S0272-7358(97)00058-5

Melchert, T. P. (1998b). Testing the validity of an instrument for assessing family of origin history. Journal of Clinical Psychology, 54, 863-876. doi:http://dx.doi.org/10.1002/ (SICI)1097-4679(199811)54:7<863::AIDJCLP1>3.0.CO;2-G

Ministry of Health. (2008). Indicadores do SUS: Vol. 5. Prevenção de Violência e Cultura de Paz II. Brasília, DF: Organização Pan-Americana da Saúde. Retrieved from http://bvsms.saude.gov. br/bvs/publicacoes/painelindicadores_sus_n5 p1.pdf

Moraes, C. L., Hasselmann, M. H., \& Reichenheim, M. E. (2002). Adaptação transcultural para o português do instrumento "Revised Conflict Tactics Scale (CTS2)" utilizado para identificar violência entre casais. Caderno de Saúde Pública, 18(1), 163-176. doi:10.1590/S003489102010000400010

O’Leary, K. D., Slep, A. M. S., \& O’Leary, S. G. (2007). Multivariate models of men's and women's partner aggression. Journal of Consulting and Clinical Psychology, 75, 752-764. doi:10.1037/0022-006X.75.5.752

Pico-Alfonso, M. A., Echeburúa, E., \& Martinez, M. (2008). Personality disorder symptoms in women as a result of chronic intimate male partner violence. Journal Family Violence, 23(7), 577 588. doi:10.1007/s10896-008-9180-9

Reingle, J. M., Jennings, W., Connell, N. M., Businelle, M. S., \& Chartier, K. (2014). On the pervasiveness of event-specific alcohol use, general substance use, and mental health problems as risk factors for intimate partner violence. Journal of Interpersonal Violence, 29(16), 1-20. doi:10.1177/0886260514527172

Rempel, J., Ross, M., \& Holmes, J. (2001). Trust and communicated attributions in close relationships. Interpersonal Relations and Group
Processes, 81(1), 57-64. doi:10.1037//00223514.81.1.57

Roberts, A. L., McLaughlin, K. A., Conron, K. J., \& Koenen, K. C. (2011). Adulthood stressors, history of childhood adversity, and risk of perpetration of intimate partner violence. American Journal of Preventive Medicine, 40(2), 128-138. doi:10.1016/j.amepre.2010.10.016

Ross, J. (2011). Personality and situational correlates of self-reported reasons for intimate partner violence among women versus men referred for Batterers' Intervention. Behavioral Sciences and the Law, 29(5), 711-727. doi:10.1002/bsl.1004

Ross, J. M., \& Babcock, J. C. (2009). Proactive and reactive violence among intimate partner violent men diagnosed with antisocial and borderline personality disorder. Journal of Family Violence, 24(8), 607-617. doi:10.1007/s10896009-9259-y

Stith, S. M., Rosen, K. H., Middleton, K. A., Busch, A. L., Lundeberg, K., \& Carlton, R. P. (2000). The intergenerational transmission of spouse abuse: A meta-analysis. Journal of Marriage and the Family, 62, 640-654. doi:10.1111/ j.1741-3737.2000.00640.x

Straus, M. A. (2011). Gender symmetry and mutuality in perpetration of clinical-level partner violence: Empirical evidence and implications for prevention and treatment. Aggression and Violent Behavior, 16(4), 279-288. doi:10.1016/j. avb.2011.04.010

Straus, M. A., Hamby, S. L., Boney-Mccoy, S., \& Sugarman, D. B. (1996). The revised Conflict Tactics Scales (CTS2): Development and preliminary psychometric data. Journal of Family, 17(3), 283-316. doi:10.1177/019251396017003001

Thomas, M. D., Bennett, L. W., \& Stoops, C. (2013). The treatment needs of substance abusing batterers: A comparison of men who batter their female partners. Journal of Family Violence, 28(2), 121-129. doi:10.1007/s10896-012-94794

Thornton, A. J., Graham-Kevan, N., \& Archer, J. (2010). Adaptive and maladaptive personality traits as predictors of violent and nonviolent offending behavior in men and women. Agressive Behavior, 36(3), 177-186. doi:10.1002/ab.20340

Treboux, D., Crowell, J., \& Waters, E. (2004). When "New" meets "Old": Configurations of adult attachment representations and their implications for marital functioning. Developmental 
Psychology, 40(2), 295-314. doi:10.1037/00121649.40.2.295

Vives-Cases, C., Álvarez-Dardet, C., \& Caballero, P. (2003). Intimate partner violence in Spain. Gaceta Sanitaria, 17(4), 268-274. Retrieved from https://www.ncbi.nlm.nih.gov/ pubmed/12975049

Walsh, Z., O’Connor, B. P., Shea, M. T., Swogger, M. T., Schonbrun, Y. C., \& Stuart, G. L. (2010). Subtypes of partner violence perpetrators among male and female psychiatric patients. Journal of Abnormal Psychology, 119(3), 563-574. doi:10.1037/a0019858

Wareham, J., Boots, D. P., \& Chavez, J. M. (2009). A test of social learning and intergenerational transmission among batterers. Journal of Criminal Justice, 37(2), 163-173. doi:10.1016/j.jcrimjus.2009.02.011

Weinstein, Y., Oltmans, T. F., \& Gleason, M. E. (2012). Borderline but not antisocial personality disorder symptoms are related to self-reported partner aggression in Late Middle-Age. Journal of Abnormal Psychology, 121(3), 692-698. doi:10.1037/a0028994

Widom, C. S., Czaja, S. J., \& Dutton, M. A. (2008). Childhood victimization and lifetime revictimization. Child Abuse and Neglect, 32, 785-796. doi:10.1016/j.chiabu.2007.12.006
Whisman, M. A., \& Schonbrun, Y. C. (2009). Social consequences of borderline personality disorder symptoms in a population-based survey: Marital distress, marital violence, and marital disruption. Journal of Personality Disorder, 23(4), 410-415. doi:10.1521/pedi.2009.23.4.410

White, H. R., \& Widom, C. S. (2003). Intimate partner violence among abused and neglected children in young adulthood: The mediating effects of early aggression, antisocial personality, hostility, and alcohol problems. Aggressive Behavior, 29(4), 332-345. doi:10.1002/ab.10074

Yoshihma, M., \& Horrocks, J. (2010). Risk of intimate partner violence: Role of childhood sexual abuse and sexual initiation in women in Japan. Children and Youth Services Review, 32(1), 2837. doi:10.1016/j.childyouth.2009.06.013

Received: 16/03/2016

$1^{\text {st }}$ revision: $30 / 11 / 2016$

$2^{\text {nd }}$ revision: $1 \% 02 / 2017$

Accepted: 1\%02/2017

(C) The Author(s), 2018. Open Access. This article is distributed under the terms of the Creative Commons Attribution 4.0 International License (http://creativecommons.org/licenses/by/4.0/), which permits unrestricted use, distribution, and reproduction in any medium, provided you give appropriate credit to the original author(s) and the source, provide a link to the Creative Commons license, and indicate if changes were made. 